\title{
BMJ Open Cross-sectional study of mental health and sexual behaviours for Ebola Survivors in Beni, Butembo and Katwa health zones of the Democratic Republic of Congo
}

\author{
Lynn Lieberman Lawry (D) , ${ }^{1}$ Nancy Stroupe Kannappan, ${ }^{2}$ Covadonga Canteli, ${ }^{3}$ \\ William Clemmer ${ }^{4}$
}

To cite: Lieberman Lawry L, Stroupe Kannappan N, Canteli C, et al. Cross-sectional study of mental health and sexual behaviours for Ebola Survivors in Beni, Butembo and Katwa health zones of the Democratic Republic of Congo. BMJ Open 2022;12:e052306. doi:10.1136/ bmjopen-2021-052306

- Prepublication history and additional supplemental material for this paper are available online. To view these files, please visit the journal online (http://dx.doi.org/10.1136/ bmjopen-2021-052306)

Received 13 April 2021 Accepted 02 December 2021

\section{Check for updates}

(c) Author(s) (or their employer(s)) 2022. Re-use permitted under CC BY-NC. No commercial re-use. See rights and permissions. Published by BMJ.

${ }^{1}$ Preventive Medicine and Biostatistics, Uniformed Services University, Bethesda, Maryland, USA

${ }^{2}$ Monitoring, Evaluation,

Research and Learning, IMA

World Health, Washington, DC, USA

${ }^{3}$ Consulting Statistician, Perales de Tajuña, Spain

${ }^{4}$ Health, IMA World Health, Goma, Democratic Republic of the Congo

Correspondence to Dr Lynn Lieberman Lawry; lynn.lawry@usuhs.edu

\section{ABSTRACT}

Objectives To understand the prevalence of mental health disorders in Ebola-affected communities and their association with condom use.

Design Cross-sectional study.

Setting Beni, Butembo and Katwa health zones, Democratic Republic of Congo (DRC).

Participants 223 adult Ebola survivors, 102 sexual partners and 74 comparison respondents.

Primary and secondary outcome measures Posttraumatic stress disorder (PTSD), depression, anxiety, substance use, suicidal ideation and attempts, stigma, condom use and sexual behaviour.

Results Most respondents reported to be married, Christian, from the Nande ethnic group, and farmers/ herders. Survivors met symptom criteria for depression at higher rates than partners $(23.5 \%(95 \% \mathrm{Cl} 18.0$ to 29.1$)$ vs 5.7 (1.2 to 10.1); $p<0.001)$. PTSD symptom criteria for survivors $(24.1 \%, 95 \% \mathrm{Cl} 18.5 \%$ to $29.7 \%)$ and partners $(16.7 \%, 95 \% \mathrm{Cl} 9.4 \%$ to $23.9 \%)$ were four times greater than the comparison participants $(6.0 \%, 95 \% \mathrm{Cl} 0.6 \%$ to $11.4 \%$ ). Two times as many survivors as partners reported that sexual activity precautions were discussed at discharge $(71.5 \%$ (95\% Cl 65.6 to 77.5$)$ vs $36.2 \%$ (95\% $\mathrm{Cl} 26.9$ to 45.5$) ; \mathrm{p}<0.001$ ). The majority of survivors (95.0 (95\% Cl $85.1 \%$ to $98.5 \%)$ and partners $98.5 \%(95 \% \mathrm{Cl}$ $89.6 \%$ to $99.8 \% ; p=0.26$ ) participated in risky sexual behaviour after the survivor left the Ebola treatment centre. The ability to refuse sex or insist on condom use before Ebola had a threefold increase in the odds of condom use (adjusted OR 3.3, 95\% $\mathrm{Cl} 1.7$ to $6.1, \mathrm{p}<0.001$ ). Up to $36 \%$ of the comparison group held discriminatory views of survivors.

Conclusions The new outbreaks in both Guinea and DRC show Ebola remains in semen longer than previously known. Understanding and addressing condom non-use and updating condom use guidelines are necessary to protect against future Ebola outbreaks, especially among sexual partners who did not have similar access to health information regarding sexual transmission of Ebola. Mental health treatment and decreasing stigma in Ebola areas is a priority.

\section{Strengths and limitations of this study}

- This randomly sampled study of adult Ebola survivors represents the entire adult survivor population in Beni, Butembo and Katwa health zones or $52 \%$ of all survivors in the 10th Ebola outbreak in the Democratic Republic of Congo.

- This cross-sectional study assesses how sexual partners, married and unmarried and the community are given information about the sexual transmission of Ebola.

- The study reveals that the new outbreaks of Ebola can be related to the lack of access to information regarding the sexual transmission of Ebola for partners of survivors, especially if they are unmarried partners.

- The weighted findings of this study cannot be generalised to the entire population of survivors in other health zones or child survivors.

- Some outcomes of interest, when stratified by specific categories, had very small sample sizes, potentially affecting the precision of estimates.

\section{INTRODUCTION}

The Ebola virus disease (EVD), first described in the Democratic Republic of Congo (DRC) in 1976 (then Zaire) occurs regularly throughout West and Central Africa. ${ }^{1}$ The second largest and longest lasting global outbreak, besides the West African outbreak, occurred in Eastern DRC starting 1 August 2018, and ending, 22 months later, in 25 June 2020. ${ }^{2}$ There were 2287 deaths reported among 3470 confirmed and probable cases, with an overall case fatality ratio of $66 \% .^{2}$ More than half $(57 \%)$ of those infected were women due to cultural practices, the role of women as caregivers for sick family members, their roles as healthcare providers and the high rates of gender-based violence in the affected areas. ${ }^{2-4}$ The EVD epidemic 
was complicated by the fact that these areas are chronically insecure and largely rural and was also marked by the deaths of healthcare providers, largely due to misinformation, rumours and misunderstandings of EVD. ${ }^{4-7}$ Post-EVD, psychosocial distress, post-traumatic stress, depression, anxiety, stigma and discrimination among EVD survivors in the West Africa and DRC outbreaks are prevalent and widespread. ${ }^{8-11}$

After the West African Ebola epidemic, post-Ebola sequela and viral persistence in bodily fluids were documented with EVD re-emergence attributable to sexual transmission by EVD survivors. ${ }^{12} 13$ Thus, survivors from the Eastern DRC 10th outbreak are followed monthly (until 2022), to include semen or breast milk screening for viral persistence/clearance. ${ }^{2}$ Further outbreaks, since the 10th outbreak, show sexual transmission of EVD occurs much longer than the previously determined 500 days. ${ }^{14}$ There is some suggestion, among survivors in West Africa and survivors from the 9th DRC EVD outbreak in Equateur province, that stigma was exacerbated by discrimination of survivors due to the understanding that EVD is sexually transmitted. ${ }^{1516}$ Stigma, however, was not associated with mental health among survivors or partners in eastern DRC (10th outbreak). ${ }^{8}$ Given low rates of condom use at baseline (3\%) in DRC and the prolonged risk of re-emergence of EVD from sexual transmission, we performed a cross-sectional study of survivors, their sexual partners and a comparison population in health zones (HZs) of North Kivu province with the highest numbers of survivors relative to other HZs. ${ }^{17} 18$ A previous publication reviewed the predictors of mental health disorders in this population. ${ }^{8}$ The intersection of mental health symptoms, stigma and discrimination may impact condom use in EVD-affected populations. This is a concern given that EVD is a sexually transmitted disease, and condom use may limit further infection and recurrent infections. This study aimed to understand if a wider range of mental health disorders (post-traumatic stress disorder (PTSD), depression, anxiety, substance use, suicidal ideation and attempts) and specific symptoms within these disorders are associated with risky sexual behaviours, stigma and condom use among eastern DRC Ebola survivors, their sexual partners and the community. This study is the first to assess mental health symptoms and understand sexual behaviour among Ebola-affected communities (not just survivors). ${ }^{8}$ These data add to the understanding of the sexual behaviours of communities in EVD outbreak areas and help to make recommendations for prevention of future EVD outbreaks in eastern DRC.

\section{METHODS}

\section{Survey sites and sample selection}

This cross-sectional survey was conducted in February, July and September 2020 in Beni, Butembo and Katwa HZs in North Kivu province of DRC. Sample size was determined by the known prevalence of depression of 0.4 . ${ }^{4}$ The sample size required to estimate that prevalence via a simple random sample, within 0.05 with $95 \% \mathrm{CI}$, was 199 survivors. To account for refusals, the targeted sample was a total of 225 survivors to represent the entire population of survivors in target HZs. Male and female EVD survivors were eligible if aged $\geq 18$ years and could present a certificate from the Ebola treatment centre (ETC). Ebola Survivor Association lists, with 427 eligible adult survivors, were used to systematically sample the entire list to reach the desired $\mathrm{n}=75$ per HZ ${ }^{19}$ Mabalako $\mathrm{HZ}$ was excluded due to insecurity (online supplemental methods). One current sexual partner, identified by the survivor, was surveyed. The target sample size for partners was 225 . We were only able to interview $45 \%(102 / 225)$ due to partners being away from households for work, not wanting to participate in a lengthy interview, and/or not wanting to talk about their experiences due to stigma. We attempted to interview a representative number of female survivors $(\sim 57 \%)$ as they had higher infection rates than men during this outbreak. ${ }^{2}$ The target sample size for the comparison group was 75 of which $74 / 75$ (99\%) were interviewed. In Katwa and Butembo, unmatched comparison interviews were randomly selected within the same villages as the survivor using a random number skip pattern from the survivor household. In Beni HZ, one avenue in each health area and two households were chosen randomly (online supplemental methods). The comparison group was not a survivor and did not have any household members who contracted EVD during the 10th outbreak. This group was surveyed to compare knowledge and attitudes and practices among those with household-level Ebola experiences versus those without such experiences.

\section{Instruments}

We used domains, except for EVD-related questions, from instruments previously developed, implemented and validated for DRC to adapt and develop a survey for survivors, their sexual partners and a version for the comparison group. ${ }^{42021}$ The major domains of this survey included demographics, experiences during discharge from the ETC, EVD knowledge, stigma, condom use and risky sexual behaviour. ${ }^{22}$ Participants self-reported their ethnic group to ensure equal participation and representation in this study. Symptom assessment of mental health was measured by the Hopkins Symptom Checklist (HSCL-25) used to assess symptoms of depression (15 items) and anxiety (10 items) and by the Harvard Trauma Questionnaire (HTQ) to assess PTSD symptoms (16 items). ${ }^{23} 24$ Both the HSCL-25 and the HTQ have been used internationally and in conflict-affected samples and were previously tested and validated in DRC. ${ }^{25-28}$ The translated versions of the instruments used for this study have been previously tested and validated in eastern DRC. ${ }^{28}$ Questions about substance abuse (using illicit drugs or alcohol more than two times per week or to excess each time), suicidal ideation and suicide attempts among respondents were reported as yes or no responses. ${ }^{29}$ The survey was written in English, translated to Kiswahili, back translated 
to account for culturally sensitive wording and reviewed for content validity. All questions on the survey were pilot tested to establish clarity of questions and cultural appropriateness. ${ }^{4021}$

\section{Interviewers}

Four local EVD-vaccinated interviewers were trained over 3 days to conduct one-on-one interviews. Interviewers learnt to verbally administer the survey in Kiswahili and Kinande and checked for accuracy by members of the research team. Interviews were conducted anonymously in a setting that offered privacy and confidentiality, typically inside the housing unit or outside away from others to preserve confidentiality. Approved by the ethics review committees, oral rather than written consent was obtained because of the high illiteracy rate and the need for confidentiality. Participants did not receive any material compensation. They were informed that participation or lack thereof would not affect their access to or the quality of the care they receive and were explicitly given the right to refuse participation. Tablets were used to limit data loss and to allow for remote data quality monitoring. The interviewers were supervised throughout the survey period, and data were uploaded at the end of the day and reviewed nightly.

\section{Statistical analysis}

XLSTAT and Stata were used to perform the statistical analyses and involved the estimation of weighted population and subpopulation means and percentages. The sample was stratified by three different HZs (Beni, Butembo and Katwa) and equal numbers of survivors, partners and comparisons sampled per HZ. To allow for an approximate probability-proportional-to-size sampling strategy, existing information on HZ population data was provided by DRC, District Health Information Service V.2.0. Data were weighted to account for population differences of each HZ and the numbers of survivors per HZ. Weights were generated for each HZ sampled and by interview groups and applied to estimates (online supplemental tables 1 and 2) Pearson $\chi^{2}$ test or Fisher's exact was used for categorical variables and two-tailed t tests for continuous variables. An F test was used to determine whether variance could be assumed to be equal. Variable selection for multivariate models was based on previous knowledge of confounding and model specification tests. Differences were considered statistically significant with a $\mathrm{p}$ value $<0.05$. An average HSCL-25 and HTQ score of $\geq 1.75$ was considered predictive of depression (HSCL-25) or clinically significant anxiety (HSCL-25), based on data from other conflict-affected populations. ${ }^{252728} 3031$ The HTQ is the most widely used measure for assessing PTSD across postconflict societies of diverse cultural backgrounds. ${ }^{24} 26$ The PTSD symptoms assessed conform to the three-factor structure (re-experiencing, avoidance/numbing and arousal) of Diagnostic and Statistical Manual of Mental Disorders, fourth edition, text revision (DSM-IV-TR). ${ }^{24}{ }^{26}$ The HTQ has been adapted and translated into multiple languages, being applied to conflict-affected and refugee populations from diverse regions of the world, including DRC where it has been validated. ${ }^{24}{ }^{26}$ An average HTQ score of $\geq 1.75$ is considered predictive of PTSD based on data from other conflict-affected populations and among populations in the EVD outbreak areas of DRC. ${ }^{24}{ }^{26}$ The reporting of this study conforms to the Strengthening the Reporting of Observational Studies in Epidemiology (STROBE) statement.

\section{Patient and public involvement}

The Ebola Survivor Associations of Beni, Butembo and Katwa were involved in identifying participants and in dissemination of the results.

\section{RESULTS \\ Characteristics of participants}

Most respondents reported to be married, Christian, from the Nande ethnic group, farmers/herders and Kiswahili speakers (table 1). A total of 223 survivors, 102 partners and 74 comparison respondent completed the survey (online supplemental table 3), with overall response rates of $90 \%-94 \%$ (online supplemental table 4). Survivors were more likely to be a widow/widower due to Ebola $(12.7 \%, 95 \%$ CI $8.3 \%$ to $17.1 \%$; $\mathrm{p}<0.001)$ than comparison respondents. The comparison group had the highest rate of never married $(30.6 \%, 95 \%$ CI $20.0 \%$ to $41.3 \%$; $\mathrm{p}<0.001)$. One-fifth of survivors were unemployed/not working $(20.2 \%, 95 \%$ CI $14.9 \%$ to $25.5 \%$; $\mathrm{p}<0.001)$. Survivors and partners were less educated than the comparison group. Survivor households had a $60 \%$ decrease in weekly median household income (US\$17.57 95\% CI US $\$ 14.48$ to US $\$ 20.66$; median US $\$ 10.00$ before EVD; US $\$ 8.6995 \%$ CI US $\$ 6.80$ to US $\$ 10.58$; median US $\$ 4.00$ after EVD; p=0.02) from August 2018 to July 2020.

\section{Characteristics of Ebola Treatment Centre discharge}

Survivors, on average, were discharged from the ETC 15 months (95\% CI $14.5 \%$ to $15.6 \%$ ) prior to the survey (table 2). Although most survivors $(98.7 \%$, 95\% CI 97.2\% to $100.0 \%$ ) reported that their partners were called to the ETC for discharge discussions, less than two-thirds (64.7\%, 95\% CI $55.4 \%$ to $73.9 \%)$ of partners stated they were present for discharge instructions with only a third of never married partners reported being called to the ETC. When asked to recall specific instructions, $78.3 \%$ of survivors (95\% CI $72.9 \%$ to $83.7 \%$ ) and $49.8 \%$ of partners (95\% CI $40.1 \%$ to $59.5 \%$ ) stated sexual activity precautions (survivors: $71.5 \%, 95 \%$ CI $65.6 \%$ to $77.5 \%$ ) and partners; $36.2 \%, 95 \%$ CI $26.9 \%$ to $45.5 \%$ ) followed by male condom use. Less than half of survivors $(45.2 \%$, $95 \% \mathrm{CI} 38.5 \%$ to $51.9 \%)$ and partners $(35.5 \%$, $95 \% \mathrm{CI}$ $26.1 \%$ to $44.9 \%$ ) received written discharge instructions.

\section{Mental health}

More males $(47.2 \%, 95 \%$ CI $40.0 \%$ to $54.3 \%)$ than females $(21.9 \%, 95 \%$ CI $16.3 \%$ to $27.6 \%)$ and partners 
Table 1 Demographic characteristics of the study participants

\begin{tabular}{|c|c|c|c|c|c|}
\hline & $\begin{array}{l}\text { EVD survivors } \\
(\mathrm{n}=223)\end{array}$ & $\begin{array}{l}\text { Partners } \\
(n=102)\end{array}$ & $\begin{array}{l}\text { Comparison group } \\
(n=74)\end{array}$ & p-value* & p-value* \\
\hline & $\begin{array}{l}\text { Weighted \% } \\
(95 \% \mathrm{Cl})\end{array}$ & $\begin{array}{l}\text { Weighted \% } \\
(95 \% \mathrm{Cl})\end{array}$ & $\begin{array}{l}\text { Weighted \% } \\
(95 \% \mathrm{Cl})\end{array}$ & $\begin{array}{l}\text { Survivor vs } \\
\text { partner }\end{array}$ & $\begin{array}{l}\text { Survivor vs } \\
\text { comparison }\end{array}$ \\
\hline Age (years)† & 35.5 (33.8 to 37.1$)$ & 33.5 (31.6 to 35.3$)$ & 38.4 (35.0 to 41.8 ) & 0.12 & $0.11 \ddagger$ \\
\hline $\begin{array}{l}\text { How long lived in } \\
\text { the survey area } \\
\text { (years)† }\end{array}$ & 20.9 (19.0 to 22.9$)$ & 18.7 (16.3 to 21.1$)$ & 19.4 (16.1 to 22.7 ) & 0.16 & 0.43 \\
\hline Marital status & & & & $<0.001$ & $<0.001$ \\
\hline Married & 56.2 (49.7 to 62.7 ) & 74.6 (66.2 to 83.0$)$ & 61.2 (50.0 to 72.5$)$ & & \\
\hline Never married & $13.9(9.4$ to 18.5$)$ & $1.8(0$ to 4.4$)$ & 30.6 (20.0 to 41.3$)$ & & \\
\hline $\begin{array}{l}\text { Widowed by } \\
\text { Ebola }\end{array}$ & 12.7 (8.3 to 17.1$)$ & $0(0$ to 0$)$ & 0 (0 to 0$)$ & & \\
\hline Widowed & 4.0 (1.4 to 6.5$)$ & 0 (0 to 0$)$ & $4.9(0$ to 9.8$)$ & & \\
\hline $\begin{array}{l}\text { Divorced/ } \\
\text { separated }\end{array}$ & $1.8(0.1$ to 3.6$)$ & $0(0$ to 0$)$ & $1.9(0$ to 5.1$)$ & & \\
\hline Partner left & 1.1 (0 to 2.4$)$ & 0 (0 to 0$)$ & 0 (0 to 0$)$ & & \\
\hline \multicolumn{6}{|l|}{ Religion } \\
\hline Christian & 100.0 & 100.0 & 100.0 & & \\
\hline Ethnic group & & & & 0.54 & 0.03 \\
\hline Nande & 91.7 (88.0 to 95.3$)$ & 96.5 (92.9 to 100.0$)$ & 85.5 (77.4 to 93.6$)$ & & \\
\hline Other ${ }^{\star *}$ & 4.7 (1.9 to 7.5$)$ & 3.5 (0 to 7.1$)$ & 4.2 (0 to 8.9$)$ & & \\
\hline Other†† & 22.6 (17.1 to 28.1$)$ & 20.7 (12.9 to 28.6$)$ & 15.2 (7.0 to 23.5$)$ & & \\
\hline Not working & 20.2 (14.9 to 25.5$)$ & 14.3 (7.5 to 21.1$)$ & 14.3 (6.2 to 22.3$)$ & & \\
\hline Small business & 19.4 (14.2 to 24.6$)$ & 15.9 (8.8 to 22.9$)$ & 15.8 (7.4 to 24.2$)$ & & \\
\hline \multicolumn{6}{|c|}{ Weekly household income $†$} \\
\hline $\begin{array}{l}\text { Before Ebola } \\
\text { (US\$) }\end{array}$ & $\begin{array}{l}17.57(14.48 \text { to } 20.66) \\
\text { Median=10.00 }\end{array}$ & $\begin{array}{l}16.59(12.25 \text { to } 20.92) \\
\text { Median }=10.00\end{array}$ & $\begin{array}{l}27.78(5.72 \text { to } 49.85) \\
\text { Median=5.00 }\end{array}$ & 0.72 & 0.37 \\
\hline $\begin{array}{l}\text { After Ebola } \\
\text { (US\$) }\end{array}$ & $\begin{array}{l}8.69(6.80 \text { to } 10.58) \\
\text { Median }=4.00\end{array}$ & $\begin{array}{l}10.56(7.89 \text { to } 13.24) \\
\text { Median=7.00 }\end{array}$ & $\begin{array}{l}24.45(7.64 \text { to } 41.27) \\
\text { Median=5.00 }\end{array}$ & 0.27 & 0.07 \\
\hline $\begin{array}{l}\text { Change since } \\
\text { Ebola (US\$) }\end{array}$ & $\begin{array}{l}-8.93(-11.66 \text { to } 6.2) \\
\text { Median }=-4.50\end{array}$ & $\begin{array}{l}-5.83(-8.55 \text { to } 3.11) \\
\text { Median }=0.00\end{array}$ & $\begin{array}{l}-3.09(-14.4 \text { to } 8.23) \\
\text { Median }=0.00\end{array}$ & 0.09 & 0.02 㧊 \\
\hline $\begin{array}{l}\text { Highest } \\
\text { education level } \\
\text { attended }\end{array}$ & & & & 0.70 & 0.00 \\
\hline Primary & 29.9 (23.9 to 35.9 ) & 35.0 (25.8 to 44.3$)$ & 35.5 (24.5 to 46.5$)$ & & \\
\hline Secondary & 47.0 (40.5 to 53.6$)$ & 45.9 (36.3 to 55.6$)$ & 36.4 (25.3 to 47.4 ) & & \\
\hline None & 11.6 (7.4 to 15.8$)$ & 11.0 (4.9 to 17.0 ) & 2.6 (0 to 6.3) & & \\
\hline University & 11.5 (7.3 to 15.7$)$ & 8.1 (2.8 to 13.4$)$ & 25.5 (15.5 to 35.5$)$ & & \\
\hline Able to read & 85.5 (80.9 to 90.2$)$ & $92.3(87.1$ to 97.5$)$ & 92.0 (85.6 to 98.2 ) & 0.09 & 0.04 \\
\hline
\end{tabular}


Table 1 Continued

\begin{tabular}{|c|c|c|c|c|c|}
\hline & $\begin{array}{l}\text { EVD survivors } \\
(\mathrm{n}=223)\end{array}$ & $\begin{array}{l}\text { Partners } \\
(n=102)\end{array}$ & $\begin{array}{l}\text { Comparison group } \\
(\mathrm{n}=74)\end{array}$ & p-value* & p-value* \\
\hline & $\begin{array}{l}\text { Weighted \% } \\
(95 \% \mathrm{Cl})\end{array}$ & $\begin{array}{l}\text { Weighted \% } \\
(95 \% \mathrm{Cl})\end{array}$ & $\begin{array}{l}\text { Weighted \% } \\
(95 \% \mathrm{Cl})\end{array}$ & $\begin{array}{l}\text { Survivor vs } \\
\text { partner }\end{array}$ & $\begin{array}{l}\text { Survivor vs } \\
\text { comparison }\end{array}$ \\
\hline $\begin{array}{l}\text { How many living } \\
\text { in the household } \\
\text { currently } †\end{array}$ & 7.2 (6.8 to 7.6$)$ & 6.9 (6.4 to 7.3$)$ & 6.7 (6.0 to 7.3 ) & 0.27 & 0.16 \\
\hline $\begin{array}{l}\text { Number of } \\
\text { household } \\
\text { members with } \\
\text { EVD† (range) }\end{array}$ & 1.4 (1.2 to 1.6$)$ & 1.9 (1.6 to 2.2 ) & 0 (0 to 0$)$ & 0.00 & $<0.0001$ \\
\hline
\end{tabular}

Bold $p$ values indicate statistical significance.

${ }^{*}$ Categorical variables: Pearson $\mathrm{x}^{2}$ test; continuous variables: two tailed t-test, prior use of an F-test to determine whether variance can be assumed to be equal. Missing values $n<1$ unless specifically noted. †Weighted means.

$\ddagger P$-value is a two-tailed. Both a two-tailed and one-test applied to test for significance. Neither produced a significant result. $\S$ Missing data excluded: survivor $n=5$, partner $n=3$.

ПMissing data: survivors $n=9$, partners $n=10$, comparisons $n=7$.

${ }^{* *}$ Includes n $\leq 2$; Baluba, Boa, Budu, Bunza, Hema, Hemba, Kongo, Lega, Lete, Luba, Lulu, Pere, Tetla, Zimba.

††Other includes $\mathrm{n}<20$ includes construction, modern/traditional healthcare provider; $\mathrm{n}<10$ teacher, tailor, non-governmental organisation (NGO) worker, food service, big business, secretary, sex worker, mechanic, soccer player, hair dresser, military, government worker, housewife, driver, student, security officer, clerical, professional.

$\ddagger \ddagger$ One outlier excluded due to reported weekly household income of 800 US\$. The change in income was -300 US\$, which was 100 times larger than the group difference of (average) -3.09 .

EVD, Ebola virus disease.

(50.8\%, $95 \%$ CI $41.1 \%$ to $60.5 \%)$ versus survivors $(23.9 \%$, $95 \%$ CI $18.3 \%$ to $29.5 \%$ ) reported current substance abuse (table 3). More than four times as many survivors $(23.5 \%, 95 \%$ CI $18.0 \%$ to $29.1 \%$; $\mathrm{p}<0.001)$ met symptom criteria for depression than their partners $(5.7 \%$, $95 \%$ CI $1.2 \%$ to $10.1 \%$ ). Cronbach alpha in our sample, for depression, was 0.76 . More than two times as many survivors $(19.2 \%, 95 \%$ CI $14.0 \%$ to $24.3 \%)$ met symptom criteria for anxiety when compared with partners $(7.6 \%$, $95 \% \mathrm{CI} 2.5 \%$ to $12.8 \% ; \mathrm{p}=0.01)$ and the comparison group $(8.1 \%, 95 \%$ CI $1.9 \%$ to $14.3 \%$; $\mathrm{p}=0.02)$. Cronbach alpha in our sample, for anxiety, was 0.90 . Survivors had four times the symptom criteria for PTSD $(24.1 \%, 95 \%$ CI $18.5 \%$ to $29.7 \% ; \mathrm{p}=0.001)$, then partners $(16.7 \%, 95 \% \mathrm{CI}$ $9.4 \%$ to $23.9 \%$ ) and 2.5 times the symptom criteria of the comparison group $(6.0 \%, 95 \%$ CI $0.6 \%$ to $11.4 \%)$. Cronbach alpha in our sample, for PTSD, was 0.91. Suicide attempts among survivors $(7.9 \%, 95 \%$ CI $4.3 \%$ to $11.4 \%)$ were six times higher than the comparison group.

\section{EVD transmission awareness and sexual risk behaviour}

All respondents were aware that the virus can persist for 10-16 months in semen. Although comparison respondents included bats/bushmeat as a common cause of EVD, $19 \%$ (95\% CI 10.1 to 28.0 ) stated that EVD was brought to the area by the 'government' and $14 \%$ (95\% CI 5.9 to 21.7) by 'non-governmental organisations' (online supplemental table 5). Sixteen per cent $(16.0 \%$ (95\% CI $11.2 \%$ to $20.8 \%)$ ) of survivors believed they contacted EVD from the health centre. Across the respondent groups, more than $50 \%$ agreed that women have sexual negotiation power and more than $48 \%$ agreed that women can refuse to have sex and/or insist on condom use. Condom use at last sexual contact was rare (10\%) among comparison respondents and higher (29\%) among survivors and partners (table 4). Twenty-one per cent of partners and the comparison group had multiple sexual partners. Disclosure of EVD exposure or infection was not common among survivors and especially partners with multiple partners and those who used commercial sex; however, there was a higher rate of condom use among survivors reporting sex with multiple partners and sex workers. Just over a third of survivor's partners used condoms when having sex with anyone other than their partner. The majority of survivors and partners participated in high-risk sexual behaviour 
Table 2 Characteristics of ETC discharge among survivors and partners

\begin{tabular}{|c|c|c|c|}
\hline & EVD survivors $(n=223)$ & Partners $(n=102)$ & \multirow[b]{2}{*}{ p-value } \\
\hline & $\begin{array}{l}\text { Weighted \% } \\
(95 \% \mathrm{Cl})\end{array}$ & $\begin{array}{l}\text { Weighted \% } \\
(95 \% \mathrm{Cl})\end{array}$ & \\
\hline $\begin{array}{l}\text { How long since discharge from ETC (number of } \\
\text { months) }\end{array}$ & $15.0(14.5$ to 15.6$)$ & NA & \\
\hline $\begin{array}{l}\text { When you/your partner was discharged from the } \\
\text { ETC, were you called to the ETC for discussions } \\
\text { about his/her/your recovery before discharge?* }\end{array}$ & 98.7 (97.2 to 100.0$)$ & 64.7 (55.4 to 73.9$)$ & $<0.001$ \\
\hline Married $†$ & 99.0 (97.5 to 100.0$)$ & 64.1 (53.3 to 74.9$)$ & \\
\hline Unmarried, living with partnerł & $100.0(100.0$ to 100.0$)$ & 68.9 (50.4 to 87.4$)$ & \\
\hline Never married§ & 100.00 (100.00 to 100.00$)$ & 32.53 (0 to 100.0$)$ & \\
\hline $\begin{array}{l}\text { Discharge instructions given in a language } \\
\text { understood } \emptyset\end{array}$ & 97.9 (95.9 to 99.8$)$ & $100.0(100.0$ to 100.0$)$ & 0.26 \\
\hline $\begin{array}{l}\text { Specific instructions given at discharge for care of } \\
\text { survivor at home }\end{array}$ & 99.2 (98.1 to 100.0$)$ & 73.2 (64.6 to 81.8$)$ & $<0.001$ \\
\hline Use of condoms (male) & 78.3 (72.9 to 83.7) & 49.8 (40.1 to 59.5$)$ & $<0.001$ \\
\hline Sexual activity precautions & 71.5 (65.6 to 77.5$)$ & 36.2 (26.9 to 45.5$)$ & $<0.001$ \\
\hline Nutrition & 20.6 (15.3 to 25.9 ) & $13.3(6.7$ to 19.9$)$ & 0.12 \\
\hline Fever & $13.4(8.9$ to 17.8$)$ & $12.8(6.4$ to 19.3$)$ & 0.90 \\
\hline Bleeding & $11.1(7.0$ to 15.2$)$ & $7.0(2.1$ to 12.0$)$ & 0.25 \\
\hline Body fluid precautions & 4.3 (1.6 to 6.9$)$ & 2.4 (0 to 5.3 ) & 0.40 \\
\hline Nausea/diarrhoea & $2.1(0.2$ to 3.9$)$ & 1.7 (0 to 4.2$)$ & 0.81 \\
\hline Written discharge instructions given for home care & $45.2(38.5$ to 51.9$)$ & $35.5(26.1$ to 44.9$)$ & 0.10 \\
\hline Written instructions were in a language understood & $\begin{array}{l}93.2(88.2 \text { to } 98.3) \\
n=98\end{array}$ & $\begin{array}{l}90.1(80.3 \text { to } 100.0) \\
n=36\end{array}$ & 0.55 \\
\hline Able to read the written instructions & $\begin{array}{l}83.9 \text { (76.3 to } 91.5) \\
n=91\end{array}$ & $\begin{array}{l}89.1 \text { (78.2 to } 99.9) \\
n=33\end{array}$ & 0.48 \\
\hline
\end{tabular}

Bold $p$ values indicate statistical significance.

*Weighted per cent calculated out of total survivor and partner population: survivors $n=223$, partners $n=102$. †Weighted per cent calculated out of married survivors and married partners: survivors $n=122$, partners $n=75$. $\ddagger$ Weighted per cent calculated out of survivors and partners who live with their partner, unmarried: survivors $n=24, p a r t n e r s ~ n=25$. $\S$ Weighted per cent calculated out of survivors and partners who have not married: survivors $n=33$, partners $n=2$. qWeighted per cent calculated out of total population who received instructions: survivors $n=196$, partners $n=60$. **Instructions for when to seek medical care.

ETC, Ebola Treatment Centre; EVD, Ebola virus disease; NA, not applicable.

after the survivor left the ETC (95.0 (95\% CI $85.1 \%$ to $98.5 \%$ ), survivors; $98.5 \%$ (95\% CI $89.6 \%$ to $99.8 \%$ ), partners).

In bivariate analyses, there was no significant association between condom use and depression, PTSD, anxiety, suicidal ideation, suicide attempts, substance use, age, education level, fear of EVD or knowledge of EVD transmission. Nor were there any significant associations among specific symptoms on the HSCL-25 and the HTQ with condom use (online supplemental table 6). However, survivors and partners had a fourfold greater odds of condom use (table 5). After adjusting for sex, age, education level, fear of Ebola, Ebola knowledge and marriage status, those persons stating they or their partner were able to refuse sex or insist on condom use before Ebola had more than three times the odds of condom use than those stating they or their partner could not refuse sex or insist on a condom before Ebola (adjusted OR 3.3, $95 \%$ CI 1.7 to $6.1, \mathrm{p}<0.001)$. Due to the small number of people who used condoms and reported they could not refuse sex or insist on condoms since Ebola $(n=8)$, the ability to refuse sex or insist on condom use since Ebola was not included in the multivariate model.

\section{Stigma, discrimination and survivor community reintegration} More than one-quarter of survivors stated that they were stigmatised by healthcare workers, while $20 \%$ of the comparison group stated that they would not want a healthcare provider who survived EVD to continue seeing patients (figure 1). And although only $16 \%$ of the comparisons stated EVD survivors are stigmatised by the community, when asked more contextualised questions about community activities such as church, weddings, meetings and shopping for food, $23 \%-36 \%$ stated survivors were 


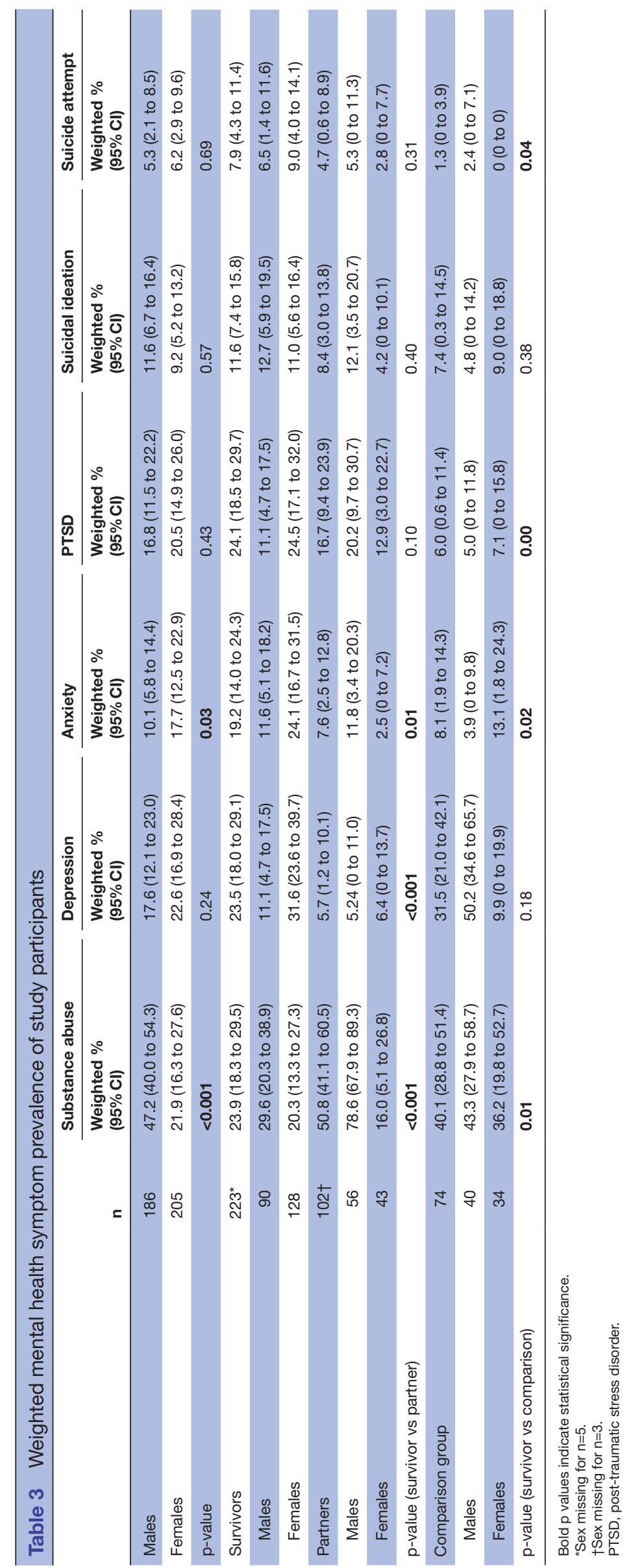


Table 4 Sexual behaviour among study participants

\begin{tabular}{|c|c|c|c|c|c|}
\hline & EVD survivors $(n=219)$ & $\begin{array}{l}\text { Partners } \\
(n=100)\end{array}$ & $\begin{array}{l}\text { Comparison group } \\
(\mathrm{n}=73)\end{array}$ & p value* & p value* \\
\hline & Weighted \% (95\% Cl) & Weighted \% (95\% Cl) & Weighted \% (95\% Cl) & $\begin{array}{l}\text { Survivor vs } \\
\text { partner }\end{array}$ & $\begin{array}{l}\text { Survivor vs } \\
\text { comparison }\end{array}$ \\
\hline Stated sex has changed since EVD† & $51.0(44.4$ to 57.7$)$ & 37.0 (27.5 to 46.5$)$ & 2.7 (0 to 6.5$)$ & 0.14 & $<0.001$ \\
\hline \multicolumn{6}{|l|}{ Sexual negotiation } \\
\hline $\begin{array}{l}\text { Agreement that women have sexual } \\
\text { negotiation power }(n=391)\end{array}$ & $61.0(54.5$ to 67.5$)(n=218)$ & $61.1(51.6$ to 70.7$)(n=100)$ & $51.1(39.6$ to 62.7$)(n=73)$ & 0.64 & 0.19 \\
\hline $\begin{array}{l}\text { Agreement that women can refuse sex } \\
\text { and/or insist on condom use }(n=392)\end{array}$ & $67.3(61.1$ to 73.5$)(n=219)$ & $64.2(54.8$ to 73.6$)(n=100)$ & $47.7(36.2,59.2)(n=73)$ & 0.14 & 0.01 \\
\hline $\begin{array}{l}\text { Before EVD, I/my partner can refuse sex } \\
\text { and/or insist on condom use }(n=392)\end{array}$ & $17.3(12.3$ to 22.3$)(n=219)$ & $12.5(6.0$ to 19.0$)(n=100)$ & $12.5(4.9,20.1)(n=73)$ & 0.45 & 0.17 \\
\hline $\begin{array}{l}\text { Since EVD, I/my partner can refuse sex } \\
\text { and/or insist on condom use }\end{array}$ & $55.4(48.9,62.0)(n=219)$ & $64.3(54.9,73.7)(n=100)$ & $10.4(3.3,17.4)(n=73)$ & 0.09 & $<0.001$ \\
\hline \multicolumn{6}{|l|}{ Sexual behaviour and condom use } \\
\hline $\begin{array}{l}\text { Condom use discussed prior to last } \\
\text { sexual contact }(n=392)\end{array}$ & 38.3 (31.9 to 45.2$)(n=219)$ & $46.3(36.4$ to 56.5$)(n=100)$ & $11.5(5.7,21.8)(n=73)$ & 0.14 & $<0.001$ \\
\hline Have had sex since leaving ETC $(n=319)$ & & & NA & $<0.0001$ & NA \\
\hline Yes & 17.1 (12.1 to 22.5$)$ & 36.6 (27.2 to 46.1$)$ & & & \\
\hline No & 82.9. (78.0 to 87.9$)$ & 63.4 (53.9 to 72.8$)$ & & & \\
\hline $\begin{array}{l}\text { Condom use at last sexual contact } \\
(\mathrm{n}=392)\end{array}$ & $29.2(23.5$ to 35.8$)(n=217)$ & $29.9(21.6$ to 39.8$)(n=100)$ & $10.1(4.6$ to 21.0$)(n=73)$ & 0.66 & 0.001 \\
\hline Sex with multiple partners $\ddagger(n=392)$ & $11.3(7.1$ to 15.5$)(n=219)$ & $20.9(12.9$ to 28.9$)(n=100)$ & 20.6 (11.3 to 29.9$)(n=73)$ & 0.02 & 0.05 \\
\hline If yes, condom used & $75.9(59.0$ to 92.8$)(n=23)$ & $50.6(29.2$ to 72.0$)(n=22)$ & 36.5 (9.0 to 63.9$)(n=16)$ & 0.08 & 0.02 \\
\hline EVD status disclosed $(n=45)$ & $36.9(17.9$ to 55.9$)(n=23)$ & $5.7(0$ to 15.7$)(n=22)$ & NA & 0.01 & NA \\
\hline $\begin{array}{l}\text { Sex with anyone other than your partner } \\
(n=392)\end{array}$ & $12.1(8.5$ to 17.4$) n=219$ & $21.6(15.0$ to 31.4$) n=100$ & $18.7(11.5$ to 30.0$)(n=73)$ & 0.006 & 0.008 \\
\hline If yes, condom used ( $n=66)$ & 76.1 (55.7 to 89.0$)(n=26)$ & $37.2(19.2$ to 59.7$)(n=24)$ & $25.9(6.8$ to 62.3$)(n=16)$ & 0.005 & 0.003 \\
\hline EVD status disclosed $(n=50)$ & $35.6(18.7$ to 57.1$)(n=26)$ & $5.4(1.2$ to 21.5$)(n=24)$ & NA & 0.01 & NA \\
\hline Commercial sex $(n=392) \ddagger$ & $4.4(2.3$ to 8.2$)(n=219)$ & $10.6(5.8$ to 18.6$)(n=100)$ & 7.9 (3.5 to 16.9$)(n=73)$ & 0.03 & 0.11 \\
\hline Condom used $(n=28)$ & $62.5(27.7$ to 87.9$)(n=10)$ & $55.9(25.3$ to 82.5$)(n=11)$ & $34.7(7.1$ to 78.7$)(n=7)$ & 0.47 & 0.09 \\
\hline EVD status disclosed $(n=21)$ & $57.5(24.4$ to 85.0$)(n=10)$ & $17.4(3.5$ to 55.1$)(n=11)$ & NA & 0.04 & NA \\
\hline High risk sexual behaviour§ $(n=78)$ & $95.0(85.1$ to 98.5$)(n=37)$ & $98.5(89.6$ to 99.8$)(n=41)$ & NA & 0.26 & NA \\
\hline
\end{tabular}

Missing data: survivors $n=70$, partners $n=43$, comparison $n=41$.

*Wald test.

†'Before/since EVD' refers to before epidemic started (before August 2018), since EVD refers to after August 2018.

FFor the comparison group, 'since/after EVD' refers to since/after EVD epidemic started (August 2018). For survivors, since discharge from the ETC and for comparisons, since the EVD epidemic started (August 2018).

§Components of risk: Applicable for survivors and partners only; Since leaving the ETC (i) had sex since leaving the ETC, but did not use a condom at last sexual contact, (ii) had sex with anyone other than your partner and not using a condom or (iii) no condom use with multiple partners; or (iv) no condom use during commercial sex.

ETC, Ebola Treatment Centre; EVD, Ebola virus disease; NA, not applicable.

Table 5 Significant associations of condom use with characteristics of the study sample

\begin{tabular}{|c|c|c|c|c|c|}
\hline Characteristic & n (\%) & 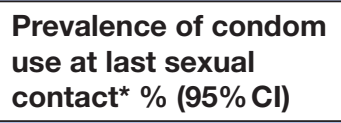 & $\begin{array}{l}\text { Crude OR } \\
(95 \% \mathrm{Cl})\end{array}$ & $\begin{array}{l}\text { aOR† } \\
(95 \% \mathrm{Cl})\end{array}$ & p value \\
\hline Survivor & $213(55.9)$ & 29.2 (23.5 to 35.8$)$ & 3.9 (1.7 to 9.0$)$ & 4.0 (1.7 to 9.5$)$ & 0.002 \\
\hline Partner & $100(25.6)$ & 29.9 (21.6 to 39.8$)$ & 4.4 (1.8 to 10.7$)$ & 4.3 (1.7 to 10.9$)$ & 0.002 \\
\hline
\end{tabular}

*Unweighted.

†Adjusted for sex, age, education level, fear of Ebola, Ebola knowledge and marriage status.

$\ddagger$ Wald test. 


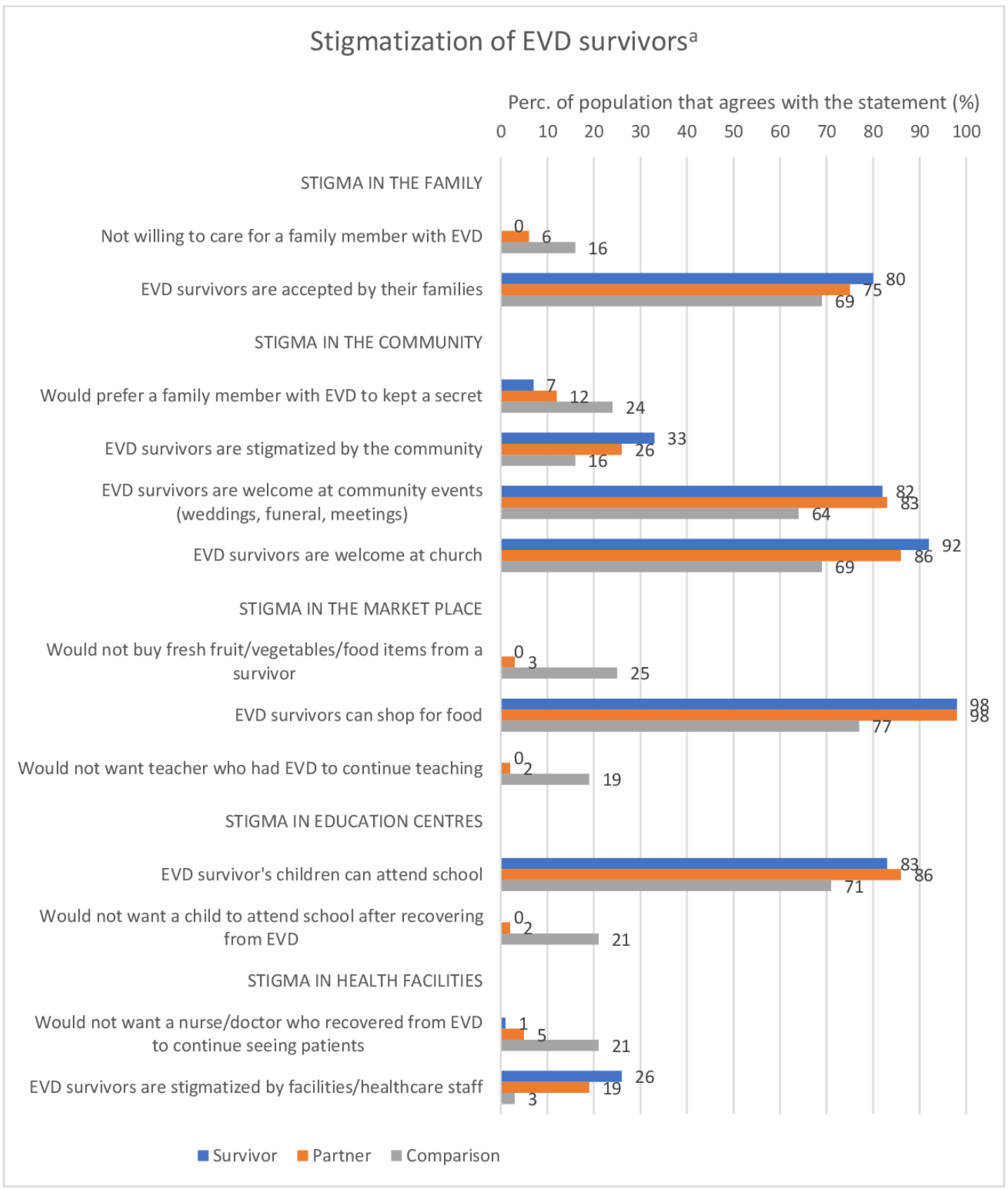

Figure 1 Stigmatisationof EVD survivors. EVD, EVD, Ebola virus disease.

not welcome in these activities. Among survivors, $20 \%$ stated that they were not accepted by their families, which was consistent among the comparison group who were not willing to care for a family member with EVD $(16.5 \%$, $95 \%$ CI $8.0 \%$ to $25.1 \%$ ) and would prefer that EVD status of a family member remains a secret $(24.0 \%, 95 \%$ CI $11.4 \%$ to $30.6 \%)$. Stigma was not associated with condom use (online supplemental table 6).

\section{DISCUSSION}

\section{Post-ETC discharge}

More than a year after discharge, $20 \%$ of survivors were unemployed/not working, which may explain the $60 \%$ drop in weekly household income. Food and nutritional assistance for survivors ended 1 year postdischarge from the ETC leaving survivors putting their families at risk for food insecurity. ${ }^{32} 33$ The baseline food insecurity in the outbreak areas, lack of employment and decrease in household income, particularly of survivors, require an assessment to determine a more realistic length of food and nutrition assistance for survivors and their families. Furthermore, meeting basic needs is a necessary step for improving mental health as 'psychological first aid'. ${ }^{34}$ Whereas unmarried partners living with survivors are considered common-law marriage, survivors may not have disclosed sexual partners not living with them due to perceived immorality of premarital sex in DRC. ${ }^{35} 36$ Sexual partners, excluded from discharge instructions, 
would not have benefited from discussions about condom use. This poses difficulty in EVD containment given that sexual transmission of EVD can be up to 5 years postrecovery. ${ }^{12-14}$

\section{Mental health}

Given the poor mental health at baseline in these postconflict/insecure outbreak areas, targeted prevention messaging must take into account past human rights violations, subsequent trauma and the possible retraumatisation due to fear and death during an outbreak of EVD to effectively prevent subsequent outbreaks. ${ }^{48113738}$ Although, in eastern DRC, it is impossible to attribute Ebola as the cause of the higher rates of mental health disorders among survivors, retraumatisation from fear and death around survivors and their families could exacerbate baseline symptoms of PTSD, which become socially disabling and contributed to the higher suicide attempt rates among survivors. ${ }^{49} 1137$ Without long-term culturally contextualised trauma-informed models of mental healthcare and psychosocial support programmes for survivors and partners, a much longer and sustained approach to address psychosocial consequences of EVD, including supplying basic needs, will be necessary. ${ }^{8} 93739$ The high rates of substance abuse and depression among all respondents suggest that mental health access is necessary for the entire community. Our rates are consistent with other studies of mental health disorders among survivors, but we include a broader survey of disorders and assess these same disorders among sexual partners of survivors and a comparison sample among community members. ${ }^{4-11} 162021$ It should also be noted that it is difficult to compare mental health symptoms in eastern DRC to those described in other DRC EVD outbreak areas due to the unique context of longterm conflict and insecurity seen in eastern DRC. ${ }^{8} 16$ Although survivors are offered psychological support at monthly follow-up appointments, lay counsellors, already trained in cognitive processing therapy, could be helpful to this population of survivors, sexual partners and the community in addressing mental health disorders. ${ }^{81128} 39-41$

\section{Risky sexual behaviour}

Known factors for risky sexual behaviours include age, poverty, violence, substance abuse, poor access to healthcare, stigma, mental health disorders (especially PTSD) and recent conflict-all factors are documented in the EVD survey areas but are not associated with condom use or risky sexual behaviour in this survey population. ${ }^{47384243}$ These factors may create a greater likelihood of risky sexual behaviour that can prolong and perpetuate the epidemic. ${ }^{42}{ }^{43}$ Previous data have shown that women's ability to negotiate sex and condom use in the survey areas is limited. ${ }^{4}$ Among this study sample, the prevalence of survivors and partners who agreed that women have sexual negotiation power was likely driven by fear of contracting EVD and possibly by the increased case and fatality rates among women. ${ }^{44}$ Since the West Africa EVD outbreak, the sexual transmission of EVD changed condom use advice for survivors and partners. ${ }^{12} 131745$ However, the use of condoms was limited among survivors and partners and especially the comparison sample. ${ }^{4647}$ The high rates of risky sexual behaviour among survivors and partners and lack of disclosure of EVD exposure among those with multiple partners and those who frequented commercial sex create a significant risk for EVD resurgence and spread. ${ }^{12}{ }^{14}$ The lack of messaging among the community regarding sexual transmission of EVD may help explain the risky sexual behaviours among the comparison group. ${ }^{40} 4647$ Furthermore, a large proportion of unmarried partners was not included in discussions of EVD sexual transmission risk at the time of discharge. Female partners, not present at discharge, would be unlikely to know that condom use is life saving and negotiation for use, imperative. ${ }^{48} 49$

\section{Stigma and community reintegration}

Mental health symptoms, especially depression, both exacerbate stigma and are exacerbated by stigmatisation. ${ }^{98}$ Despite sensitisation efforts to decrease stigma among communities in outbreak areas, the prevalence of fear-based stigma, not unlike other studies, will likely impede the quality of care and access to necessary post-EVD mental healthcare and perpetuate the spread of EVD. ${ }^{8163738405051}$ Access to care will be an important factor for educating survivors and partners about data showing long-term sexual transmission of EVD. ${ }^{12}{ }^{14}$ As in other studies of EVD survivors, pervasive self-reported stigma led to societal exclusion for themselves and family members and was likely exacerbated by the new sexually transmitted cases of EVD reported in Guinea. ${ }^{145051}$ In outbreak areas, the use of innovative sustainable community led and financed approaches such as Champion Communities or Noyaux Communitaire already used in DRC, would help engage community members in decreasing stigma and subsequently their health and mental health. ${ }^{5253}$

\section{Limitations}

The weighted findings of this study represent the adult survivor populations in Beni, Butembo and Katwa HZs and cannot be generalised to the entire population of survivors in other HZs or child survivors. The sample weights are based on population estimates and therefore may introduce bias given, there is no recent census data to rely on. ${ }^{54}$ Interviewers explained that there would be no material gain by participation in the study. Certain sexual behaviours (eg, use of sex workers) and mental health symptoms may be underreported due to social norms that prevent them from 
being discussed openly. Respondents may have underestimated or exaggerated responses if they thought it would be in their interest to do so. The mental health instruments used do not substitute for clinician diagnosis. The cross-sectional design of this study allows for the determination of population characteristics but not causality. Additionally, small sample sizes after stratification limited the analyses that could be performed for associations between some predictors and outcomes.

\section{CONCLUSIONS AND IMPLICATIONS FOR PRACTICE}

These findings have direct application for the care of EVD survivors and their families and EVD prevention efforts. ${ }^{8556}$ An assessment of condom use guidelines and discharge instructions are necessary to protect against future EVD outbreaks, especially among sexual partners who did not have similar access to health information regarding the sexual transmission of EVD and new evidence that EVD remains in body fluids for longer than previously understood. ${ }^{12-14} 57$ This guidance needs to come from the WHO and at the country level. All sexual partners, married or unmarried, must be included in discussions at discharge from ETCs to ensure that partners are informed about the sexual transmission of EVD and help survivors and partners understand what constitutes risky sexual behaviour. Risk communication campaigns and condom use messaging during the epidemic targeted survivor men and did not empower partner women to insist on condom use and need a change to include messages to partners, building women's empowerment and decreasing risk among community members. ${ }^{40}$ Behaviour change communication must also emphasise partner notification to limit sexual transmission of EVD. Furthermore, non-partners such as sex workers are at a higher risk for Ebola as few if any survivors informed them of their EVD infection. ${ }^{40}$ The ability to insist on condom use would prevent further infection transmission. ${ }^{48} 49$ Condom use, including barriers and facilitators to use, in EVD-affected populations in eastern DRC needs to be studied further using mixed methods.

Given the fear and mistrust in outbreak areas $(96 \%$ of the sample feared Ebola), community led groups will be essential in addressing continued stigma, mental health, dispelling myths, creating positive norms and attitudes and supplying basic needs for survivors. ${ }^{7815164150-5355-58}$ Finally, WHO and countries affected by EVD need contextualised messaging. Fear-based messaging was common during the 10th epidemic, which influenced the beliefs of where the virus originated, how people were infected and changed behaviour such as immunising children. ${ }^{7858}$ Addressing myths and censoring those who perpetrate myths would go a long way to ensuring information is evidence-based. ${ }^{758}$ Creating positive societal norms such as improving women's empowerment for asking for condom use and/or refusing sex would be important as a preventive measure to ensure that future outbreaks are limited given the strong association between positive norms and condom use in this population. Although risk-based campaigns have limited effectiveness, in specific instances, where acquiring an untreatable and ultimately fatal disease is likely, such campaigns may influence sexual behaviour and limit spread. ${ }^{937} 385960$ However, it will be important to make sure that these campaigns do not further stigmatise survivors and their families. 915165051 Finally, understanding and acknowledging the prevalence and cause of fear in outbreak areas, diminishing misinformation and harnessing that fear for action that has public health relevance will be an important step in limiting future outbreaks. ${ }^{973858-60}$

Contributors LLL, NSK and CC had full access to the data in the study and take responsibility for the integrity of the data and the accuracy of the data analysis. LLL accepts full responsibility for the work and/or the conduct of the study, had access to the data, and controlled the decision to publish. Study concept and design: LLL, NSK, CC. Acquisition of data: LLL. Analysis and interpretation of data: LLL and NSK. Drafting of the manuscript: LLL. Critical revision of the manuscript for important intellectual content: LLL, NSK, WC, CC. Statistical analysis: CC, LLL and NSK. Obtained funding: NSK and WC. Administrative, technical or material support: NSK, LLL, WC. Study supervision: LLL.

Funding This study was made possible by the generous funding of IMA World Health and its contributing donors.

Competing interests None declared.

\section{Patient consent for publication Not applicable.}

Ethics approval This study involves human participants and was approved by Comité D'Ethique, Université Libre Des Pays Des Grand Lacs (ULPGL) \#2019 Western Institutional Review Board (Study number: 1264919), Université de Kinshasa Ecole De Sante Publique Comite D'Ethique (Ref number ESP/CE 245/2019) Uniformed Services University of the Health Sciences (Ref number 916785). Participants gave informed consent to participate in the study before taking part.

Provenance and peer review Not commissioned; externally peer reviewed.

Data availability statement Data are available upon reasonable request. All requests for data must be sent in writing to IMA World Health.

Supplemental material This content has been supplied by the author(s). It has not been vetted by BMJ Publishing Group Limited (BMJ) and may not have been peer-reviewed. Any opinions or recommendations discussed are solely those of the author(s) and are not endorsed by BMJ. BMJ disclaims all liability and responsibility arising from any reliance placed on the content. Where the content includes any translated material, BMJ does not warrant the accuracy and reliability of the translations (including but not limited to local regulations, clinical guidelines, terminology, drug names and drug dosages), and is not responsible for any error and/or omissions arising from translation and adaptation or otherwise.

Open access This is an open access article distributed in accordance with the Creative Commons Attribution Non Commercial (CC BY-NC 4.0) license, which permits others to distribute, remix, adapt, build upon this work non-commercially, and license their derivative works on different terms, provided the original work is properly cited, appropriate credit is given, any changes made indicated, and the use is non-commercial. See: http://creativecommons.org/licenses/by-nc/4.0/.

\section{ORCID iD}

Lynn Lieberman Lawry http://orcid.org/0000-0001-8229-8768

\section{REFERENCES}

1 World Health Organization. Ebola virus disease, 2020. Available: https://www.who.int/news-room/fact-sheets/detail/ebola-virusdisease [Accessed 13 Nov 2020]. 
2 World Health Organization. Ebola virus disease - Democratic Republic of Congo, 2020. Available: https://www.who.int/csr/don/26June-2020-ebola-drc/en/ [Accessed 13 Nov 2020]

3 United Nations Population Fund. New Ebola outbreak hits women and girls hardest in the Democratic Republic of the Congo, 2018. Available: https://www.unfpa.org/news/new-ebola-outbreak-hitswomen-and-girls-hardest-democratic-republic-congo. $=[$ Accessed 13 Nov 2020].

4 Johnson K, Scott J, Rughita B, et al. Association of sexual violence and human rights violations with physical and mental health in territories of the eastern Democratic Republic of the Congo. JAMA 2010;304:553-62.

5 United Nations High Commission of Refugees. UNHCR position on returns to North Kivu, South Kivu, Ituri and adjacent areas in the Democratic Republic of Congo affected by ongoing conflict and violence-Update 2, 2019. Available: https://www.refworld.org/pdfid/ 5d6d794a4.pdf [Accessed 13 Nov 2020].

6 Insecurity Insight. Overview of attacks on health care in the DRC, 2019. Available: http://insecurityinsight.org/wp-content/uploads/ 2019/12/Overview-Attacks-on-Health-Care-in-the-DRC-Jan-Nov2019.pdf [Accessed 13 Nov 2020].

7 Vinck P, Pham PN, Bindu KK, et al. Institutional trust and misinformation in the response to the 2018-19 Ebola outbreak in North Kivu, DR Congo: a population-based survey. Lancet Infect Dis 2019;19:529-36.

8 Lawry LL, Stroupe Kannappan N, Canteli C, et al. Mixed-Methods assessment of health and mental health characteristics and barriers to healthcare for Ebola survivors in Beni, Butembo and Katwa health zones of the Democratic Republic of Congo. BMJ Open 2021;11:e050349.

9 James PB, Wardle J, Steel A, et al. Post-Ebola psychosocial experiences and coping mechanisms among Ebola survivors: a systematic review. Trop Med Int Health 2019:24:671-91.

10 Cénat JM, Felix N, Blais-Rochette C, et al. Prevalence of mental health problems in populations affected by the Ebola virus disease: a systematic review and meta-analysis. Psychiatry Res 2020;289:113033.

11 Kaputu-Kalala-Malu C, Musalu EM, Walker T, et al. PTSD, depression and anxiety in Ebola virus disease survivors in Beni town, Democratic Republic of the Congo. BMC Psychiatry 2021;21:1-8.

12 Soka MJ, Choi MJ, Baller A, et al. Prevention of sexual transmission of Ebola in Liberia through a national semen testing and counselling programme for survivors: an analysis of Ebola virus RNA results and behavioural data. Lancet Glob Health 2016;4:e736-43.

13 Wilson HW, Amo-Addae M, Kenu E, et al. Post-Ebola syndrome among Ebola virus disease survivors in Montserrado County, Liberia 2016. Biomed Res Int 2018;2018:1-8.

14 Virological. Guinea 2021 EBOV outbreak. Available: https:// virological.org/t/guinea-2021-ebov-outbreak/643 [Accessed 13 Mar 2021].

15 Venables E. 'Atomic bombs' in Monrovia, Liberia: the identity and stigmatisation of Ebola survivors. Anthropol Action 2017;24:36-43.

16 Cénat JM, Kokou-Kpolou CK, Mukunzi JN, et al. Ebola virus disease, stigmatization, peritraumatic distress, and posttraumatic stress disorder in the Democratic Republic of the Congo: a moderated mediation model. J Affect Disord 2021;293:214-21.

17 Democratic Republic of Congo. Demographic health survey 2013-14, 2014. Available: https://dhsprogram.com/pubs/pdf/SR218/SR218.e. pdf [Accessed 13 Nov 2020].

18 United Nations Population Fund, 2012. Available: https://www.unfpa. org/sites/default/files/resource-pdf/FINAL_Democratic_Republic_of_ the_Congo.pdf [Accessed 13 Nov 2020].

19 United Nations Child Fund. Ebola survivors serving their communities, 2020. Available: https://www.unicef.org/drcongo/en/ stories/ebola-survivors-serving-their-community [Accessed 13 Nov 2020].

20 Lawry L. A population-based household study to assess practical strategies of prevention and response to sexual and gender based violence in Katana, Walikale, and Karisimbi health zones, DRC, 2016. Available: https://imaworldhealth.org/wp-content/uploads/ 2016/11/OSC-IMA-Ushindi-Baseline-2016-.pdf [Accessed 13 Nov 2020].

21 Lawry L. Overcoming sexual and gender-based violence in eastern Democratic Republic of Congo, 2016. Available: https:// imaworldhealth.org/wp-content/uploads/2016/12/OSC-IMA-UshindiImpact-Evaluation-Final.pdf [Accessed 13 Nov 2020].

22 The Joint United Nations Programme on HIV/AIDS. National AIDS programmes: a guide to monitoring and evaluation, 2000. Available: https://www.who.int/hiv/pub/me/pubnap/en/ [Accessed 13 Nov 2020].
23 Veijola J, Jokelainen J, Läksy K, et al. The Hopkins symptom Checklist-25 in screening DSM-III-R axis-I disorders. Nord J Psychiatry 2003;57:119-23.

24 Harvard Trauma Questionnaire (HTQ), 2011. Available: http://hprtcambridge.org/screening/harvard-trauma-questionnaire/ [Accessed 13 Nov 2020].

25 Tsutsumi A, Izutsu T, Poudyal AK, et al. Mental health of female survivors of human trafficking in Nepal. Soc Sci Med 2008:66:1841-7.

26 Mollica RF, Caspi-Yavin Y, Bollini P, et al. The Harvard trauma questionnaire. validating a cross-cultural instrument for measuring torture, trauma, and posttraumatic stress disorder in Indochinese refugees. J Nerv Ment Dis 1992;180:111-6.

27 Ventevogel P, De Vries G, Scholte WF, et al. Properties of the Hopkins symptom Checklist-25 (HSCL-25) and the self-reporting questionnaire (SRQ-20) as screening instruments used in primary care in Afghanistan. Soc Psychiatry Psychiatr Epidemiol 2007:42:328-35.

28 Bass JK, Annan J, Mclvor Murray S, et al. Controlled trial of psychotherapy for Congolese survivors of sexual violence. $N$ Engl $J$ Med 2013;368:2182-91.

29 National Institutes of Health. Suicide and suicidal behavior, 2020. Available: http://www.nlm.nih.gov/medlineplus/ency/article/001554. htm\#Definition [Accessed 13 Nov 2020].

30 Mollica RF, Wyshak G, de Marneffe D, et al. Indochinese versions of the Hopkins symptom Checklist-25: a screening instrument for the psychiatric care of refugees. Am J Psychiatry 1987;144:497-500.

31 McDonald SD, Calhoun PS. The diagnostic accuracy of the PTSD checklist: a critical review. Clin Psychol Rev 2010;30:976-87.

32 World Food Program. WFP's response to the Ebola outbreak in DRC 2018. Available: https://reliefweb.int/report/democratic-republiccongo/wfp-s-response-ebola-outbreak-drc-19-november-2018 [Accessed 16 Oct 2020].

33 Congressional Research Service. Ebola outbreaks in the Democratic Republic of Congo: emergencies or enduring threat? 2020. Available: https://crsreports.congress.gov/product/pdf/R/R45933 [Accessed 16 Oct 2020].

34 Interagency Standing Committee. Guidelines on mental health and psychosocial support during emergencies, 2007. Available: https:// www.who.int/mental_health/emergencies/guidelines_iasc_mental_ health psychosocial june 2007.pdf [Accessed 26 Oct 2020].

35 Annan-Yao E. African gender research in the new millenium: gender relations and perspectives, directions and challenges social institutions/processes, 2000. Available: https://codesria.org/lMG/pdf/ ANNANYAO-1.pdf [Accessed 13 Nov 2020].

36 Family Code, 1987, Art. 330, 334, 351. Government of the Democratic Republic of Congo (1987) Loi no 87/010 Du 1er août 1987 Portant code de la famille, 2016. Available: http://www.leganet. cd/Legislation/Code\%20de\%20la\%20famille/Table.htm [Accessed 13 Nov 2020].

37 O'Leary A, Jalloh MF, Neria Y. Fear and culture: contextualising mental health impact of the 2014-2016 Ebola epidemic in West Africa. BMJ Glob Health 2018;3:e000924.

38 Betancourt TS, Brennan RT, Vinck P, et al. Associations between mental health and Ebola-related health behaviors: a regionally representative cross-sectional survey in post-conflict Sierra Leone. PLoS Med 2016:13:e1002073.

39 Cénat JM, Mukunzi JN, Noorishad P-G, et al. A systematic review of mental health programs among populations affected by the Ebola virus disease. J Psychosom Res 2020;131:109966.

40 World Health Organization. Risk communication and community engagement preparedness and readiness framework: Ebola response in the Democratic Republic of Congo in North Kivu, 2018. Available: https://apps.who.int/iris/bitstream/handle/10665/275389/ 9789241514828-eng.pdf?ua=1 [Accessed 27 Oct 2020].

41 United States Agency for International Development. Overcoming sexual and gender based violence: IMA World health Ushindi project, 2019. Available: https://www.usaid.gov/faith-and-opportunityinitiatives/success-stories/jun-2019-overcoming-sexual-and-genderbased-violence-ima-world-health-ushindi-project [Accessed $13 \mathrm{Nov}$ 2020]

42 Ramrakha S, Caspi A, Dickson N, et al. Psychiatric disorders and risky sexual behaviour in young adulthood: cross sectional study in birth cohort. BMJ 2000;321:263-6.

43 Rogers G, Curry M, Oddy J, et al. Depressive disorders and unprotected casual anal sex among Australian homosexually active men in primary care. HIV Med 2003;4:271-5.

44 Gender analysis: prevention and response to Ebola virus disease in the Democratic Republic of Congo, 2020. Available: https://reliefweb. int/report/democratic-republic-congo/gender-analysis-preventionand-response-ebola-virus-disease\#: :text=The\%20reality\%20is\% 
20that\%20the,just\%2011\%25\%20of\%20EVD\%20deaths [Accessed 27 Oct 2020].

45 Kondé MK, Diop MK, Curtis MY, et al. Sex practices and awareness of Ebola virus disease among male survivors and their partners in guinea. BMJ Glob Health 2017;2:e000412.

46 Nuwaha F, Faxelid E, Höjer B. Predictors of condom use among patients with sexually transmitted diseases in Uganda. Sex Transm Dis 1999;26:491-5

47 Kapiga SH, Lwihula GK, Shao JF, et al. Predictors of AIDS knowledge, condom use and high-risk sexual behaviour among women in Dar-es-Salaam, Tanzania. Int J STD AIDS 1995;6:175-83.

48 Malow RM, Corrigan SA, Cunningham SC, et al. Psychosocial factors associated with condom use among African-American drug abusers in treatment. AIDS Educ Prev 1993;5:244-53.

49 Soler H, Quadagno D, Sly DF, et al. Relationship dynamics, ethnicity and condom use among low-income women. Fam Plann Perspect 2000;32:82.

50 James PB, Wardle J, Steel A, et al. An assessment of Ebola-related stigma and its association with informal healthcare utilisation among Ebola survivors in Sierra Leone: a cross-sectional study. BMC Public Health 2020;20:182.

51 Overholt L, Wohl DA, Fischer WA, et al. Stigma and Ebola survivorship in Liberia: results from a longitudinal cohort study. PLoS One 2018;13:e0206595.

52 Liebermann Lawry L, Barhobagayana J, Faye O. Using a modified champion community approach for improving maternal, newborn, and child health outcomes in remote and insecure health zones in the Democratic Republic of Congo 2012-2017: a case study. J Glob Health Rep 2019;3:10.29392/joghr.3.e2019068.
53 IMA World Health. Community core groups: a promising platform for integrated development, 2014. Available: https://imaworldhealth.org/ success-story-community-core-groups-a-promising-platform-forintegrated-development [Accessed 21 Sep 2021].

54 IMA World Health. District health information system 2.0 (DHIS2)., 2020. Available: https://imadrc.org/dhis2/ [Accessed 13 Nov 2020].

55 United Nations News. Latest Ebola outbreak in DR Congo is declared over, with lessons for COVID-19, 2020. Available: https://news.un. org/en/story/2020/11/1077912 [Accessed 13 Nov 2020].

56 World Food Program. With conflict and Covid-19 deepening hunger in the Democratic Republic of Congo, more help is needed to save millions of lives, 2020. Available: https://reliefweb.int/report/ democratic-republic-congo/conflict-and-covid-19-deepeninghunger-democratic-republic-congo [Accessed 13 Nov 2020].

57 World Health Organization. Ebola virus disease-Democratic Republic of Congo, 2021. Available: https://www.who.int/ emergencies/disease-outbreak-news/item/2021-DON310 [Accessed 28 Oct 2020].

58 Science. Fighting Ebola is hard. in Congo, fake news makes it harder, 2019. Available: https://www.science.org/content/article/fightingebola-hard-congo-fake-news-makes-it-harder [Accessed 6 Oct 2021].

59 Green EC, Witte K. Can fear arousal in public health campaigns contribute to the decline of HIV prevalence? J Health Commun 2006;11:245-59.

60 Nuriddin A, Jalloh MF, Meyer E, et al. Trust, fear, stigma and disruptions: community perceptions and experiences during periods of low but ongoing transmission of Ebola virus disease in Sierra Leone, 2015. BMJ Glob Health 2018;3:10.1136/bmjgh-2017-000410 